\title{
Editorial
}

\section{Special Issue on Treatment Wetlands}

\author{
Miklas Scholz ${ }^{1,2,3}$
}

1 Division of Water Resources Engineering, Faculty of Engineering, Lund University, P.O. Box 118, 22100 Lund, Sweden; miklas.scholz@tvrl.lth.se; Tel.: +46-(0)462228920

2 Department of Civil Engineering Science, School of Civil Engineering and the Built Environment, University of Johannesburg, Kingsway Campus, P.O. Box 524, Aukland Park, Johannesburg, South Africa

3 Department of Town Planning, Engineering Networks and Systems, South Ural State University (National Research University), 76 Lenin prospekt, 454080 Chelyabinsk, Russia

Citation: Scholz, M. Special Issue on Treatment Wetlands. Environments 2021, 8, 30. https://doi.org/ 10.3390 /environments 8040030

Received: 7 April 2021

Accepted: 8 April 2021

Published: 12 April 2021

Publisher's Note: MDPI stays neutral with regard to jurisdictional claims in published maps and institutional affiliations.

Copyright: (C) 2021 by the author. Licensee MDPI, Basel, Switzerland. This article is an open access article distributed under the terms and conditions of the Creative Commons Attribution (CC BY) license (https:/ / creativecommons.org/licenses/by/ $4.0 /)$.
This Special Issue is concerned with treatment wetlands, which are artificial (or constructed) wetlands usually treating municipal or industrial wastewater, greywater and storm water runoff [1]. They are engineered systems that use natural processes, vegetation, soil and organisms to treat waters. Depending on the type of wastewater, the design of the treatment wetlands must be adjusted accordingly. The primary treatment of wastewater is recommended when there is a considerable amount of large suspended matter. However, treatment wetland outflow does not usually require further purification.

Similar to natural wetlands, treatment wetlands act as a biological filter and can remove a wide range of pollutants. These wetlands have been designed to remove fine suspended solids, organic matter, pathogens and nutrients. There are two main types of treatment wetlands: subsurface-flow and surface-flow. Planted vegetation and aggregates, such as pea gravel, soil and woodchip, can play an important role in pollutant removal [1]

This issue is particularly concerned with original research in the latest developments in the wider treatment wetland area, such as innovations in operation, methods, equipment, water quality control and integrated constructed wetlands. However, communications on popular topics were also encouraged.

This issue contains four carefully selected peer-reviewed papers. The first article reports the development and application of analytical methods, such as the weak anion exchange solid-phase extraction method and high-resolution Orbitrap-mass spectrometry. These tools are demonstrated to enable the advancement of constructed wetland treatment system design and optimization, enabling (semi-)passive water treatment systems to be a viable option for, for example, oil sands process-affected water treatment [2].

A further related study [3] applied a passive sampling approach using low-density polyethylene samplers to determine the treatment efficiency of a surface flow treatment wetland for polycyclic aromatic hydrocarbons [1] in oil sands process-affected waters. The application of the passive samplers for toxicity assessment showed that, in this study, polycyclic aromatic hydrocarbons in both the influent and effluent were not expected to cause acute toxicity. Moreover, passive sampling appeared to be a useful and costeffective method for monitoring pollutants and for determining the treatment efficiency of contaminants within treatment wetlands.

Gosch et al. [4] studied a woodchip-based wetland system, which was efficient in nutrient retention. However, the system contributed to the total organic carbon load of receiving waters, which impaired the overall positive role of bioreactors, particularly within intensively agriculturally used landscapes. The authors considered this lowmaintenance biotechnology suitable for single drainage pipes with high discharge and high nitrate concentrations.

The final article [5] showed that artificial water treatment wetlands can reduce nitrogen and phosphorous nutrient concentrations in wastewater effluent to improve water quality and decrease eutrophication in natural watercourses [1]. The research focused on uric 
acid in avian and reptilian excretory products. High concentrations of about $3 \mathrm{mg} / \mathrm{L}$ uric acid were found in the wetland influent, but it drastically declined to $<0.2 \mathrm{mg} / \mathrm{L}$ in the corresponding effluent.

The papers of this Special Issue highlighted new methods, equipment, technologies and water quality control strategies of great interest to environmentalists. However, the relatively low number of articles published and the diverse nature of topics make it difficult to judge if these are strong recent trends in treatment wetland research.

Conflicts of Interest: The author declares no conflict of interest.

\section{References}

1. Scholz, M. Sustainable Water Management: Engineering Solutions for a Variable Climate; Elsevier: Amsterdam, The Netherlands, 2018.

2. Ajaero, C.; Meulen, I.V.; Simair, M.C.; le Roux, M.; Parrott, J.; Peru, K.M.; McMartin, D.W.; Headley, J.V. Developments in Molecular Level Characterization of Naphthenic Acid Fraction Compounds Degradation in a Constructed Wetland Treatment System. Environments 2020, 7, 89. [CrossRef]

3. Cancelli, A.M.; Gobas, F.A.P.C. Treatment of Polycyclic Aromatic Hydrocarbons in Oil Sands Process-Affected Water with a Surface Flow Treatment Wetland. Environments 2020, 7, 64. [CrossRef]

4. Gosch, L.; Liu, H.; Lennartz, B. Performance of a Woodchip Bioreactor for the Treatment of Nitrate-Laden Agricultural Drainage Water in Northeastern Germany. Environments 2020, 7, 71. [CrossRef]

5. Welch, J.; Simmons, V.; Meléndez, E.; Sees, M.; Gold, Y.; Heider, E.C. Assessment of Non-Anthropogenic Addition of Uric Acid to a Water Treatment Wetlands. Environments 2020, 7, 60. [CrossRef] 